DOI $10.15421 / 4220021$

UDC 539.3

\author{
H. K. Ismayilov
}

\title{
FORCED VIBRATIONS OF A INHOMOGENEOUS ORTHOTROPIC CYLINDRICAL SHELL STIFFENED WITH A CROSS-SYSTEM OF RIBS IN LIQUID
}

In the paper we study forced vibrations of an orthotropic cylindrical shell inhomogeneous in thickness and stiffened with a cross-system of ribs in liquid under the action of inner radial pressure pulsating in time. Based on Hamilton Ostrogradsky variational principle, we construct a system of equations to determine the displacements of the mid-surface points of an orthotropic cylindrical shell inhomogeneous in thickness and stiffened with a cross-system of ribs under dynamical interaction with liquid. Surface loads acting on the cylindrical shell inhomogeneous in thickness and stiffened with a cross-system of ribs as viewed from liquid are determined from the solutions of liquid motion equations written in potentials. Analytic formulas for finding the displacements of the midsurface points of a liquid-contacting orthotropic cylindrical shell inhomogeneous in thickness and stiffened with a cross-system of ribs, were obtained.

Keywords: forced vibrations; orthotropic cylindrical shell; ideal liquid; stress; stiffening; variational principle.

Introduction. To give more rigidity, the shells are stiffened with ribs, and this time slight increase in the mass of the construction increases its strength. Such constructions can be in contact with external medium and be subjected not only to statistical loads but also to dynamical ones. Strength analysis, stability and vibrations of such constructions play an important role when designing modern machines and apparatus. The paper [3] studies forced vibrations of an external liquid-contacting orthotropic longitudinally stiffened cylindrical shell inhomogeneous in thickness under the action of inner radial pressure pulsating in time. Using Hamilton - Ostrogradsky variational principle, the system of equations is structured to determine the displacements of the midsurface points of a liquid-contacting orthotropic cylindrical shell inhomogeneous in thickness and stiffened with a cross-system of ribs. Analytic formulas for finding the displacements of the midsurface points of an orthotropic cylindrical shell stiffened with a cross-system of ribs under the dynamical interaction with liquid, are found. In [4] a problem on forced axially symmetric vibrations of a liquid-filled isotropic cylindrical shell stiffened and loaded with axial compressive forces, was studied. The paper [3] was devoted to forced vibrations of a longitudinally stiffened homogeneous orthotropic cylindrical shell in liquid under the action of inner radial pressure. Analytic formulas are obtained for finding the displacements of the midsurface points of a liquid-contacting, longitudinally stiffened homogeneous orthotropic cylindrical shell. Forced vibrations of an orthotropic cylindrical shell

(C) H. K. Ismayilov, 2020 
with solid and liquid medium and stiffened with a cross-system of ribs under the action of external radial pressure pulsating in time, are studied in [6]. The surface loads acting on solid medium as viewed from liquid, are determined from the solutions of liquid motion equation written in potentials. Analytic formulas for finding the displacements of the midsurface points of a liquidcontacting, longitudinally stiffened orthotropic cylindrical shell are found.

In the paper [9] natural vibrations frequency of the system that consisting of a solid medium-filled elastic-plastic orthotropic cylindrical shell strengthened with discretely distributed rings established on a plane perpendicular to its axis is studied. Utilizing the Hamilton - Ostrogradsky principle, a frequency equation for determining vibration frequencies of the system the following consideration was created; its roots were obtained by mathematical method. In the paper [2] free vibrations of an orthotropic, laterally stiffened, ideal fluidfilled cylindrical shell inhomogeneous in thickness and in circumferential direction is studied. Using the Hamilton - Ostrogrdasky variational principle, the systems of equations of the motion of an orthotropic, ideal fluid filled cylindrical shell stiffened in thickness and circumference, are constructed.

Problem statement. A ribbed shell is considered as a system consisting of the own anisotropic shell and longitudinal, lateral ribs rigidly connected with it along the contact line (Fig. 1). It is accepted that the stress-strain state of the shell can be completely determined within the linear theory of elastic thin shells based on Kirchhoff - Liav hypothesis, and for calculation of ribs the theory of curvilinear bars is chosen so that the coordinate lines coincide with the principle curvature line of the shell midsurface. It is assumed that the ribs are located along the coordinate lines, and their edges are located like the edges of sheathing lie in the same coordinate plane.

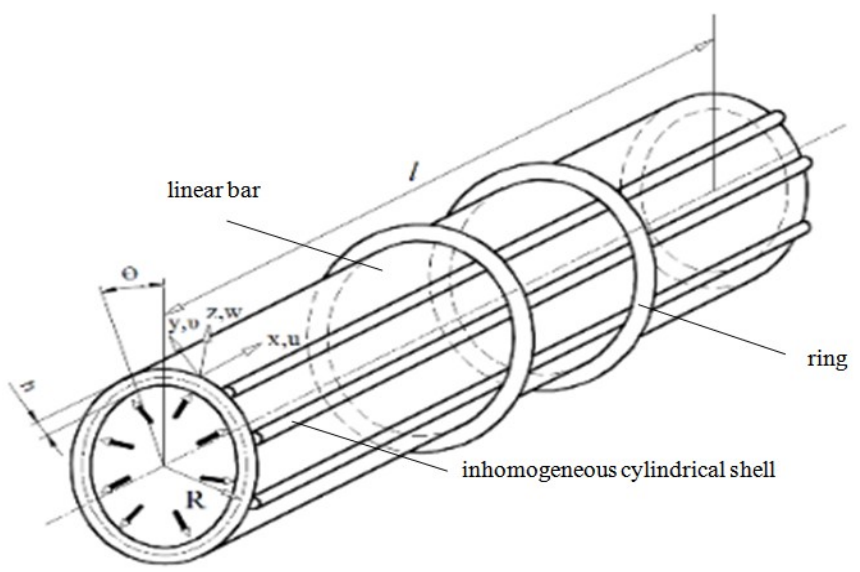

Fig. 1 - Inhomogeneous cylindrical shell reinforced with cross ribs under the action of internal pressure 
The strain state of the sheathing may be determined by three components of displacements of its midsurface, $u, \vartheta$ and $w$. This time, the rotation angles of normal elements $\varphi_{1}, \varphi_{2}$ with respect to coordinate lines $y$ and $x$ are expressed by $w$ and $\vartheta$ by means of the dependences $\varphi_{1}=-\frac{\partial w}{\partial x}, \varphi_{2}=-\left(\frac{\partial w}{\partial y}+\frac{\vartheta}{R}\right)$, where $R$ is a radius of the shell midsurface.

For describing the strain state of ribs, in addition to three components of displacements of the center of gravity of their cross sections $u_{i}, \vartheta_{i}, w_{i}$ of the $i$-th longitudinal bar and $u_{i}, \vartheta_{i}, w_{i}$ of the $j$-th lateral bar it is necessary to determine the twist angles $\varphi_{k p i}$ and $\phi_{k p j}$.

Considering that according to the accepted hypothesis we have the constancy of radial deflections and equality of appropriate twist angles following from the conditions of rigid junction of ribs with a shell, we write the following relation:

$$
\begin{aligned}
& u_{i}(x)=u\left(x, y_{i}\right)+h_{i} \varphi_{1}\left(x, y_{i}\right) ; \vartheta_{i}(x)=\vartheta\left(x, y_{i}\right)+h_{i} \varphi_{2}\left(x, y_{i}\right) ; \\
& w_{i}(x)=w\left(x, y_{i}\right) ; \varphi_{i}=\varphi_{1}\left(x, y_{i}\right) ; \varphi_{k p i}(x)=\varphi_{2}\left(x, y_{i}\right) ; \\
& u_{j}(y)=u\left(x_{j}, y\right)+h_{j} \varphi_{1}\left(x_{j}, y\right) ; \vartheta j(x)=\vartheta\left(x_{j}, y\right)+h_{j} \varphi_{2}\left(x_{j}, y\right) ; \\
& w_{j}(x)=w\left(x_{j}, y\right) ; \varphi_{j}=\varphi_{2}\left(x_{j}, y\right) ; \varphi_{k p j}(x)=\varphi_{1}\left(x_{j}, y\right) .
\end{aligned}
$$

Here $h_{i}=0,5 h+H_{i}^{1}, h_{j}=0,5 h+H_{j}^{1}, h$ is the shell thickness, $H_{i}^{1}$ and $H_{j}^{1}$ are the distances from the axis of the $i$-th longitudinal and $j$-th lateral bar to the shell surface, $x_{i}$ and $y_{i}$ are the coordinates of the line of conjunction of ribs with a shell, $\varphi_{i}, \varphi_{k p i}$ and $\phi_{j}, \phi_{k p j}$ are rotation and twisting angles of cross-sections of longitudinal and lateral bars, respectively.

For external actions it is assumed that the load surfaces acting on a ribbed shell as viewed from liquid, can be reduced to normal components $q_{z}$, applied to the shell midsurface.

Differential equations of motion and natural boundary conditions for a longitudinally stiffened orthotropic cylindrical shell with liquid under the action of axial compression are obtained by the Hamilton - Ostrogrdasky variational principle. For that we write in advance the potential and kinetic energies of the system.

There are various ways for accounting inhomogeneity of a shell material. One of them is that the Young modulus and density of the shell material are accepted as normal coordinate function [8]. It is assumed that the Poisson ratio is constant. In this case, the functional of total energy of elastic deformation of the orthotropic cylindrical shell is of the form: 


$$
\begin{gathered}
\Pi_{0}=\frac{h R}{2} \int_{x_{1}}^{x_{2}} \int_{y_{1}}^{y_{2}} \int_{-h / 2}^{h / 2}\left\{b_{11}(z)\left(\frac{\partial u}{\partial x}\right)^{2}-2\left(b_{11}(z)+b_{12}(z)\right) \frac{w}{R} \frac{\partial u}{\partial x}+\frac{w^{2}}{R^{2}}\left(b_{11}(z)+\right.\right. \\
\left.2 b_{12}(z)+b_{22}(z)\right)+b_{22}(z)\left(\frac{\partial \vartheta}{\partial y}\right)^{2}+2\left(b_{12}(z)+b_{22}(z)\right) \frac{w}{R} \frac{\partial \vartheta}{\partial y}+ \\
\left.+2 b_{12}(z) \frac{1}{R} \frac{\partial u}{\partial x} \frac{\partial \vartheta}{\partial y}+b_{66}(z)\left(\frac{\partial u}{\partial y}\right)^{2}+b_{66}(z)\left(\frac{\partial \vartheta}{\partial x}\right)^{2}+2 b_{66}(z) \frac{\partial u}{\partial y} \frac{\partial \vartheta}{\partial x}\right\} d x d y d z \\
K_{0}=h \int_{-h / 2}^{h / 2} \rho(z) \int_{x_{1}}^{x_{2}} \int_{y_{1}}^{y_{2}}\left[\left(\frac{\partial u}{\partial t}\right)^{2}+\left(\frac{\partial \vartheta}{\partial t}\right)^{2}+\left(\frac{\partial w}{\partial t}\right)^{2}\right] d x d y d z
\end{gathered}
$$

where

$$
\begin{gathered}
b_{11}(z)=\frac{E_{1}(\mathrm{z})}{1-v_{1} v_{2}} ; \quad b_{22}(z)=\frac{E_{2}(z)}{1-v_{1} v_{2}} ; \quad b_{12}(z)=\frac{v_{2} E_{1}(z)}{1-v_{1} v_{2}}=\frac{v_{1} E_{2}(z)}{1-v_{1} v_{2}} ; \\
b_{66}(z)=G_{12}(z)=G(z) .
\end{gathered}
$$

$R$ is the radius of shells midsurface, $h$ is shell thickness; $u, \vartheta, w$ are the components of displacements of the shell midsurafce points.

Suppose that

$$
E_{1}(z)=E_{10} f(z) ; \quad E_{2}(z)=E_{20} f(z) ; \quad G(z)=G_{0} f(z) ; \rho(z)=\rho_{0} f(z),
$$

where $E_{10}, E_{20}$ are elasticity module of the shell material in coordinate directions, $G_{0}$ is the shear modulus of the shell, $\rho_{0}$ is the density of the homogeneous shell material.

Allowing for (3) and (4), the total energy functional of the cylindrical shell has the form:

$$
\begin{aligned}
\Pi_{0} & =\frac{h R}{2\left(1-v_{1} v_{2}\right)} \int_{-h / 2}^{h / 2} f(z) d z \int_{x_{1}}^{x_{2}} \int_{y_{1}}^{y_{2}}\left\{E_{10}\left(\frac{\partial u}{\partial x}\right)^{2}-2\left(E_{10}+v_{1} E_{20}\right) \frac{w}{R} \frac{\partial u}{\partial x}+\right. \\
& +\frac{w^{2}}{R^{2}}\left(E_{10}+2 v_{1} E_{20}+E_{20}\right)+E_{20}\left(\frac{\partial \vartheta}{\partial y}\right)^{2}-2\left(v_{2} E_{10}+E_{20}\right) \frac{w}{R} \frac{\partial \vartheta}{\partial y}+ \\
& \left.+2 v_{2} E_{10} \frac{1}{R} \frac{\partial u}{\partial x} \frac{\partial \vartheta}{\partial y}+G_{0}\left(\frac{\partial u}{\partial y}\right)^{2}+G_{0}\left(\frac{\partial \vartheta}{\partial x}\right)^{2}+2 G_{0} \frac{\partial u}{\partial y} \frac{\partial \vartheta}{\partial x}\right\} d x d y
\end{aligned}
$$




$$
K_{0}=h \rho_{0} \int_{-h / 2}^{h / 2} f(z) d z \int_{x_{1}}^{x_{2}} \int_{y_{1}}^{y_{2}}\left[\left(\frac{\partial u}{\partial t}\right)^{2}+\left(\frac{\partial \vartheta}{\partial t}\right)^{2}+\left(\frac{\partial w}{\partial t}\right)^{2}\right] d x d y .
$$

The expressions for potential energy of elastic deformation of the $i-$ th longitudinal rib and the $j-$ th lateral bar are as follows [1]:

$$
\begin{aligned}
\Pi_{i} & =\frac{1}{2} \int_{x_{1}}^{x_{2}}\left[E_{i} F_{i}\left(\frac{\partial u_{i}}{\partial x}\right)^{2}+E_{i} J_{y i}\left(\frac{\partial^{2} w_{i}}{\partial x^{2}}\right)^{2}+E_{i} J_{z i}\left(\frac{\partial^{2} \vartheta_{i}}{\partial x^{2}}\right)^{2}+G_{i} J_{k p i}\left(\frac{\partial \varphi_{k p i}}{\partial x}\right)^{2}\right] d x ; \\
\Pi_{j} & =\frac{E_{j}}{2 R} \sum_{j=1}^{k_{2}} \int_{0}^{2 \pi}\left[F_{j}\left(\frac{\partial \vartheta}{\partial \theta}-w-\frac{h_{j} \partial^{2} w}{R \partial \theta^{2}}\right)^{1}+\frac{I_{x j}}{R^{2}}\left(\frac{\partial^{2} w}{\partial \theta^{2}}+w\right)^{2}+\right. \\
& \left.+\frac{G_{j}}{R^{2} E_{j}} I_{k p j}\left(\frac{\partial^{2} w}{\partial \xi \partial \theta}+\frac{\partial w}{\partial \theta}\right)^{2}\right]_{\xi=\xi_{j}} d \theta .
\end{aligned}
$$

Here $F_{i}, J_{z i}, J_{y i}, J_{k p i}-F_{j}, J_{z j}, J_{y j}, J_{k p j}$ is square and inertia moments of the cross-section of the $i$-th longitudinal and the $j$-th lateral bar, respectively with respect to the axis $O z$ and the axis parallel to the axis $O y$ and passing through the center of gravity of the section, and also its torsional inertia moment; $E_{i}, G_{i}-\tilde{E}_{j}, \tilde{G}_{j}$ are elasticity and shear module of the material of the $i$-th longitudinal and the $j$-th lateral bar.

The potential energy of external surface loads $\bar{q}\left(q_{x}, q_{y}, q_{z}\right)$ and loads $q_{z z}$ acting as viewed from liquid and applied to the shell is determined as a work performed by these loads when taking the system from the deformed state to the initial undeformed state and is represented as:

$$
A_{0}=-\int_{x_{1}}^{x_{2}} \int_{y_{1}}^{y_{2}}\left(q_{x}+q_{y}+q_{z}+q_{z z}\right) w d x d y .
$$

The total potential energy of the system equals the sum of potential energies of elastic deformations of the shell, longitudinal ribs and lateral ribs and also potential energies of all external loads as viewed from liquid and potential energy of radial pressure:

$$
\Pi=\Pi_{0}+\sum_{i=1}^{k_{1}} \Pi_{i}+A_{0}+\sum_{j=1}^{k_{2}} \Pi_{j} .
$$


Kinetic energies of longitudinal and lateral ribs are written as follows [1]:

$$
\begin{gathered}
K_{i}=\sum_{i=1}^{k_{1}} \rho_{i} F_{i} \int_{x_{1}}^{x_{2}}\left[\left(\frac{\partial u_{i}}{\partial t}\right)^{2}+\left(\frac{\partial \vartheta_{i}}{\partial t}\right)^{2}+\left(\frac{\partial w_{i}}{\partial t}\right)^{2}+\frac{J_{\kappa p i}}{F_{i}}\left(\frac{\partial \varphi_{\kappa p i}}{\partial t}\right)^{2}\right] d x \\
K_{j}=\rho_{j} F_{j} \int_{0}^{2 \pi}\left[\left(\frac{\partial u_{j}}{\partial t}\right)^{2}+\left(\frac{\partial \vartheta_{j}}{\partial t}\right)^{2}+\left(\frac{\partial w_{j}}{\partial t}\right)^{2}+\frac{J_{\kappa p j}}{F_{j}}\left(\frac{\partial \varphi_{\kappa p j}}{\partial t}\right)^{2}\right] d \varphi .
\end{gathered}
$$

Here $t$ is a time coordinate, $\rho_{i}, \rho_{j}$ is density of materials from which the $i-$ th longitudinal and the $j$-th lateral bar was made.

The kinetic energy of the inhomogeneous cylindrical shell stiffened with cross ribs

$$
K=K_{0}+\sum_{i=1}^{k_{1}} K_{i}+\sum_{j}^{k_{2}} K_{2}
$$

The equations of motion of a ribbed shell were obtained based on the Hamilton - Ostrogradsky principle of stationarity of action:

$$
\delta W=0,
$$

where $W=\int_{t^{\prime}}^{t^{\prime \prime}} L d t$ is Hamilton action; $L=K-\Pi$ is the Lagrange function, $t^{\prime}$ and $t^{\prime \prime}$ are the given arbitrary moments of time.

The surface load $q_{z z}$, acting as viewed from liquid on a longitudinally stiffened shell is determined from the solution of the ideal fluid motion equation [7, 10]:

$$
\Delta \varphi-\frac{1}{a_{0}^{2}} \frac{\partial^{2} \varphi}{\partial t^{2}}=0
$$

where $\varphi$ is a potential of perturbed speeds; $a_{0}$ is velocity of propagation of perturbations in liquid.

Continuity of radial speeds and pressures on the contact surface a shellliquid is observed. The condition of impermeability or smoothness of flow at the shell wall is of the form:

$$
\left.\vartheta_{r}\right|_{r=R}=\left.\frac{\partial \varphi}{\partial r}\right|_{r=R}=-\omega_{0} \frac{\partial w}{\partial t_{1}} .
$$

Equality of radial pressures on the shell as viewed from liquid

$$
q_{z z}=-p_{\mid r=R} ; q_{x}=q_{y}=0 .
$$


By means of (12), (13) and 14) we can represent the pressure $p$ as viewed from liquid on the shell in the form

$$
p=\omega_{0}^{2} \Phi_{\alpha n} \rho_{m} \frac{\partial^{2} w}{\partial t_{1}^{2}} .
$$

Here

$$
\Phi_{\alpha n}=\left\{\begin{array}{l}
K_{n}(\beta r) / \mathrm{K}_{n}^{\prime}(\beta R), \quad M_{1}<1 \\
N_{n}\left(\beta_{1} r\right) / \mathrm{N}_{n}^{\prime}\left(\beta_{1} R\right), \quad M_{1}>1 . \\
\frac{R^{n}}{n r^{n-1}}, M_{1}=1
\end{array} .\right.
$$

In (16) $t_{1}=\omega_{0} t ; M_{1}=\frac{\omega / m}{a_{0}} ; \beta^{2}=R^{-2}\left(1-M_{1}^{2}\right) \chi^{2} ; \omega_{0}=\sqrt{b_{11} /\left(\rho_{0} R^{2}\right)} ;$ $\beta_{1}^{2}=R^{-2}\left(M_{1}^{2}-1\right) \chi^{2} ; \xi=x / L ; \omega_{1}=\sqrt{\rho_{0} R^{2} \omega^{2} / b_{11}}=\omega / \omega_{0} ; \quad K_{m}$ is a modified $n$-th order Bessel function of second kind, $N_{n}$ is an $n$-th order Bessel or Neumann function of second kind.

We will assume that the orthotropic cylindrical shell stiffened with crosssystem of ribs in liquid is under the action of an inner radial pressure $q_{z}$ pulsating in time:

$$
q_{z}=q_{0} \cos n \theta \sin \frac{m \pi}{\xi_{1}} \xi \sin \omega_{1} t_{1} .
$$

Problem solution. In what follows we consider hugely supported shells, i.e. for $\xi=0$ and $\xi=\xi_{1}\left(\xi_{1}=L / R\right)$ the following boundary conditions are fulfilled:

$$
\vartheta=w=0, T_{1}=M_{1}=0 .
$$

We look for the components of displacements vector of the midsurface points of the shell in the form

$$
\begin{gathered}
u=u_{0} \cos n \theta \cos \frac{m \pi}{\xi_{1}} \xi \sin \omega_{1} t_{1} ; \quad \vartheta=\vartheta_{0} \sin n \theta \sin \frac{m \pi}{\xi_{1}} \xi \sin \omega_{1} t_{1} ; \\
w=w_{0} \cos n \theta \sin \frac{m \pi}{\xi_{1}} \xi \sin \omega_{1} t_{1}
\end{gathered}
$$

where $u_{0}, \vartheta_{0}, w_{0}$ are unknown constants. 
Using (9), (14), (15), (17), (18) and accepting $f(z)=1+\gamma z / h(\gamma$ is an inhomogeneity parameter, where $0 \leq \gamma \leq 1)$ the problem is reduced to the inhomogeneous system of third order linear algebraic equations with respect to the constants $u_{0}, \vartheta_{0}, w_{0}$ :

$$
a_{i 1} u_{0}+a_{i 2} \vartheta_{0}+a_{i 3} w_{0}=q_{i}(i=1,2,3),
$$

where $q_{1}=q_{2}=0, q_{3}=q_{0}$.

The elements $a_{i 1}, a_{i 2}, a_{i 3}(i=1,2,3)$ have a bulky form and we do not give them.

Since the system (19) is inhomogeneous, from it we get the displacement amplitudes:

$$
u_{0}=\frac{\Delta_{1}}{\Delta}, \vartheta_{0}=\frac{\Delta_{2}}{\Delta}, \quad w_{0}=\frac{\Delta_{3}}{\Delta} .
$$

Here

$$
\begin{gathered}
\Delta_{1}=q_{0}\left(a_{12} a_{23}-a_{22} a_{13}\right) ; \Delta_{2}=q_{0}\left(a_{21} a_{13}-a_{11} a_{23}\right) ; \Delta_{3}=q_{0}\left(a_{11} a_{22}-a_{21} a_{12}\right) ; \\
\Delta=a_{11} a_{22} a_{33}+a_{21} a_{32} a_{13}+a_{12} a_{23} a_{31}-a_{31} a_{22} a_{13}-a_{32} a_{23} a_{11}-a_{21} a_{12} a_{33} .
\end{gathered}
$$

Note that for $\Delta=0$ the displacement amplitudes go to infinity and this corresponds to the resonance case.

Numerical results. Let us consider some results of calculations carried out proceeding from the above dependences (18) of displacements using the finite element method.

The followings were accepted for geometrical and physical parameters characterizing the materials of the shell, liquid and longitudinal bars:

$$
\begin{gathered}
E_{i}=6,67 \cdot 10^{9} \mathrm{H} / \mathrm{m}^{2}, \rho_{0}=\rho_{i}=78 \cdot 10^{3} \mathrm{H} / \mathrm{m}^{3} ; F_{i}=3,4 \cdot 10^{-6} \mathrm{~m}^{2} ; \\
J_{y i}=5,1 \cdot 10^{-12} \mathrm{~m}^{4} ; \rho_{m} / \rho_{0}=0,105 ; J_{y i} /\left(2 \pi R^{3} h\right)=0,8289 \cdot 10^{-6} ; \\
J_{z i} /\left(2 \pi R^{3} h\right)=0,13 \cdot 10^{-6} ; R=0,16 \mathrm{M} ; \mathrm{h}=0,45 \cdot 10^{-3} \mathrm{M} ; L=0,8 \mathrm{~m} ; \\
E_{20}=25,2 \mathrm{HPa} ; G_{0}=3,5 \mathrm{HPa} ; J_{k p i} /\left(2 \pi R^{3} h\right)=0,5305 \cdot 10^{-6} ; v_{2}=0,19 ; \\
v_{1}=0,11 ; \quad h_{i}=1,39 \cdot 10^{-3} \mathrm{~m} ; a_{0}=1350 \mathrm{~m} / \mathrm{sec} ., E_{10}=18,3 \mathrm{HPa} .
\end{gathered}
$$

The dependences of $w_{0} / q$ on frequency $\omega_{1}$ for different ratios $E_{10} / E_{20}$ were represented in Fig. 2. Here solid lines correspond to $E_{10} / E_{20}=1,25$, dotted lines to- $E_{10} / E_{20}=0,25$. It can be seen from the figure that for certain frequencies the peaks of the curves go to infinity. These frequencies are resonance frequencies and are determined from the equation $\Delta=0$. Fur- 
thermore, amplification of the property of orthotropy of the shell material reduces to decrease in the value of shell deflection.

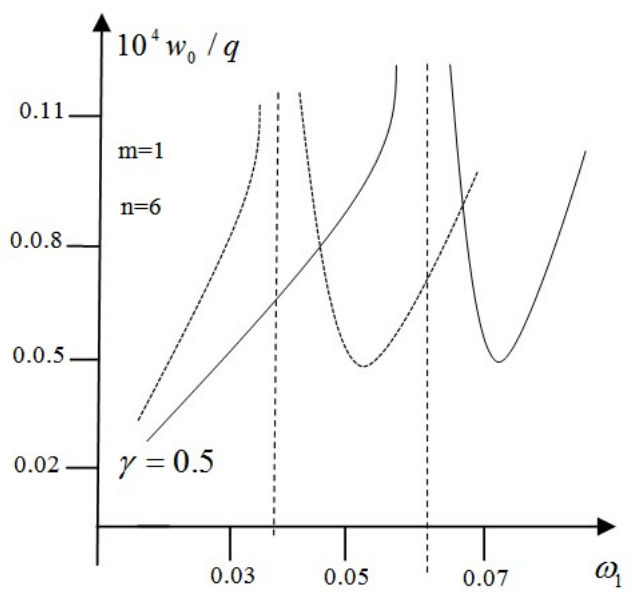

Fig.2 - Dependence of the shell deflection on the vibration frequency



Fig. 3 - Dependence of the shell deflection on the inhoogeneity parameter

The dependences of consider hun erturbations in liquid. $w_{0} / q$ on the inhomogeneity parameter $\gamma$ for different ratios $E_{10} / E_{20}$, are represented in Fig. 3. Here solid lines correspond $E_{10} / E_{20}=1,25$, the dotted lines to 
$E_{10} / E_{20}=0,75$ From the figure we can see that with increasing the inhomogeneity parameter $\gamma$ the shell's deflection decreases.

\title{
REFERENCES
}

1. Amiro I.Ya., Zarutskiy V.A. Studies in the Field of Dynamics of Ribbed Shells // Applied Mechanics, 1981. Vol. 17. JS II, P. 3-20. (in Russian).

2. Badirov Z.M. Vibrations of an Anisotropic Laterally Stiffened Fluid Filled Cylindrical Shell Inhomogeneous in Thickness and Circumference // International Journal on Technical and Physical Problems of Engineering 2020. Iss. 42. Vol. 12. No 1. P. 73-77.

3. Ismayilov H.K. Forced vibrations of a longitudinally stiffened inhomogeneous orthotropic cylindrical shell in Fluid // International Journal on Technical and Physical Problems of Engineering. 2020. Iss. 42. Vol. 12. No 1. P 35-39.

4. Latifov F.S.,. Salmanov O.Sh. A problem of forced axially-symmetric vibrations of a liquid-filled cylindrical shell stiffened and loaded with axial compressive forces // Mekhanika mashins i materialov. International scientific-technical journal. Joint Institute of Mechanical Engineering. NAS of Byelorussia. 2008. No 4(5). P. 45-48.

5. Latifov F.S., Mamedov R.A. Forced vibrations of a longitudinally stiffened orthotropic cylindrical shell in liquid // Vestnik Zaporizhsk National Univ. Cer.: Phys. math. sci. 2017. No 2. P. 131-139.

6. Latifov F.S., Musayev Z.S., Mamedrzayeva F.T. Forced vibrations of an orthotropic cylindrical shell with solid medium and liquid and stiffened with cross-system of ribs // Vestnik Zaporizhsk National Univ. Cer.: Phys. math. Sci. 2017. No. 2. P. 140-148.

7. Latifov F.S. Vibrations of Shells with Elastic and Liquid Medium, 1999. Elm, Baku, $164 \mathrm{p}$.

8. Lomakin V.I. Theory of Elasticity of Inhomogeneous Bodies. Moscow: Publication House Moscow State University,1977. 376 p.

9. Nematli A.I. "Free Orthotropic Viscous-Elastic and Medium-Contacting Cylindrical Shell Strengthened with Rings and Elastic Symmetry Axis Forms of Angle with Coordinate Axis // International Journal on Technical and Physical Problems of Engineering, 2019. Iss. 41. Vol. 11. No 4. P. 11-15.

10. Volmir A.S. Shells in Fluid and Gas Flow, Hydroelasticity Problems, Sciences, Moscow: Russia, 320 p., 1976. (in Russian).

\section{УДК 539.3}

\author{
Н. К. Ісмаїлов
}

\section{ВИМУШЕНІ КОЛИВАННЯ В РІДИНИ НЕОДНОРІДНОЇ ОРТОТРОПНОЇ ЦИЛІНДРИЧНОЇ ОБОЛОНКИ, ПІДКРІПЛЕНОЇ ПОПЕРЕЧНОЮ СИСТЕМОЮ РЕБЕР}

Досліджуються вимушені коливання неоднорідної за товщиною ортотропної циліндричної оболонки, зміцненої поперечною системою ребер, в рідини під дією пульсуючого в часі внутрішнього радіального тиску. На основі варіаційного принципу Гамільтона - Остроградського побудована система рівнянь для визначення переміщень точок їі серединної поверхні при динамічній взаємодії 3 рідиною. Поверхневі навантаження, що діють на 
неоднорідну за товщиною циліндричну оболонку, підсилену поперечною системою ребер, якщо дивитися 3 боку рідини, визначаються 3 розв'язків рівнянь руху рідини, записаних в потенціалах. Отримано аналітичні формули для визначення переміщень серединних точок контактуючої 3 рідиною ортотропной циліндричної оболонки, неоднорідної за товщиною і підсиленої поперечною системою ребер.

Ключові слова: вимушені коливання; ортотропна циліндрична оболонка; ідеальна рідина; напруження; жорсткість; варіаційний принцип.

Досліджуються вимушені коливання в ідеальній рідини неоднорідної по товщині ортотропної циліндричної оболонки, зміцненої поперечною системою ребер, під дією пульсуючого в часі внутрішнього радіального тиску.

Ребриста оболонка розглядається як система, що складається 3 власної анізотропної оболонки і поздовжніх бічних ребер, жорстко пов'язаних з нею по лінії контакту, які розташовані уздовж координатних ліній, а їхні краї розташовані так само, як і кромки обшивки, лежать в одній координатної площини. Вважається, що ортотропна циліндрична оболонка, посилена поперечної системою ребер, знаходиться в ідеальній рідини під дією пульсуючого в часі внутрішнього радіального тиску.

Напружено-деформований стан оболонки визначається в рамках лінійної теорії пружних тонких оболонок, заснованої на гіпотезі Кірхгоффра - Лява, а для розрахунку ребер обрана теорія криволінійних стрижнів таким чином, щоб координатні лінії збігалися з основною лінією кривини серединної поверхні оболонки. Деформований стан оболонки визначається за трьома компонентами переміщень її серединної поверхні і кутами повороту нормальних елементів щодо координатних ліній.

Для опису деформованого стану ребер крім трьох складових переміщень центру ваги їх поперечних перерізів поздовжнього і поперечного стрижня визначаються також кути їх повороту. 3 умов жорсткого з'єднання ребер з оболонкою приймається рівність їх радіальних прогинів і відповідних кутів кручення. Для урахування неоднорідності матеріалу оболонки модуль Юнга і щільність матеріалу оболонки приймаються змінними функціями по товщині оболонки. При цьому коефіцієнт Пуассона вважається постійним.

Для зовнішніх впливів передбачається, що поверхневі навантаження, що діють на ребристу оболонку, якщо дивитися з боку рідини, можуть бути зведені до нормальних компонентів, прикладеним до серединної поверхні оболонки. Диференціальні рівняння руху і природні граничні умови поздовжньо зміцненої ортотропной циліндричної оболонки з рідиною під дією осьового стиснення отримані за допомогою варіаційного принципу Гамільтона - Остроградського.

Після проведених перетворень задача зводиться до неоднорідної системи лінійних алгебраїчних рівнянь третього порядку щодо переміщень серединної поверхні оболонки. 


\title{
Н. К. Исмаилов \\ ВЫНУЖДЕННЫЕ КОЛЕБАНИЯ В ЖИДКОСТИ НЕОДНОРОДНОЙ ОРТОТРОПНОЙ ЦИЛИНДРИЧЕСКОЙ ОБОЛОЧКИ, ПОДКРЕПЛЕННОЙ ПОПЕРЕЧНОЙ СИСТЕМОЙ РЕБЕР
}

\begin{abstract}
Исследуются вынужденные колебания неоднородной по толщине ортотропной цилиндрической оболочки, упрочненной поперечной системой ребер, в жидкости под действием пульсирующего во времени внутреннего радиального давления. На основе вариационного принципа Гамильтона Остроградского, построена система уравнений для определения перемещений точек её срединной поверхности при динамичном взаимодействии с жидкостью. Поверхностные нагрузки, действующие на неоднородную по толщине цилиндрическую оболочку, определяются из решений уравнений движения жидкости, записанных в потенциалах. Получены аналитические формулы для определения перемещений срединных точек соприкасающейся с жидкостью ортотропной цилиндрической оболочки, неоднородной по толщине и усиленной поперечной системой ребер.
\end{abstract}

Ключевые слова: вынужденные колебания; ортотропная цилиндрическая оболочка; идеальная жидкость; напряжения; жесткость; вариационный принцип.

Institute of Mathematics and Mechanics, Azerbaijan National Academy of Sciences, Baku, Azerbaijan

Received by the Editorial Board 30.10.2020 